\title{
OBTAINING AN ACID-BASE NATURAL INDICATOR FROM THE FRUIT Punica Granatum L. (POMEGRANATE): A CONTRIBUTION FOR THE SUBSTITUTION OF SYNTHETIC INDICATORS
}

\author{
HUAROTE EMILY ${ }^{1^{*}}$, HERRERA HERNANDEZ NORA GABRIELA ${ }^{1}$ AND BORQUEZ JORGE ${ }^{2}$ \\ ${ }^{I}$ Facultad de Ciencias Naturales y Matemática, Universidad Nacional Federico Villarreal, Lima, Perú. \\ ${ }^{2}$ Departamento de Química, Facultad de Ciencias Básicas, Universidad de Antofagasta, Casilla 170, Antofagasta, 1240000, Chile.
}

\begin{abstract}
The research proposes to obtain a natural acid-base indicator from the extract of the arils of the Punica granatum L. (pomegranate) fruit as an option to replace the synthetic indicators (phenolphthalein). The indicative actions of the fruit extract Punica granatum $L$. is due to the presence of phytochemicals (anthocyanins). The identification of some of the anthocyanins present was carried out by an analysis in the UHPLC-ESI-Q-Orbitrap-MS / MS equipment, of Reverse Phase C-18. The preliminary tests for the anthocyanin test were to measure the color change of the extract against $\mathrm{HCl}$ and $\mathrm{NaOH}$, likewise a $\mathrm{pH}$ scale curve was performed and its stability was measured in different periods of time $(5,10$ and $15 \mathrm{~min})$, which were analyzed in the UV-Vis Spectrophotometer, the potentiometric acid-base titrations, determined the values of the first and second derivatives, obtaining the $\mathrm{pK}_{\text {Ind }}$ interval of the fruit extract Punica granatum L. Finally, it was confirmed that the $\mathrm{pH}$ variation is one of the factors that significantly affected the color of the extract of the Punica granatum L. fruit, while the effect of light at different time periods oxidized the extract (discoloration).
\end{abstract}

Keywords: Anthocyanin, Acid-Base Indicators, pH, Flavonoids.

\section{INTRODUCTION}

The analytical chemistry uses synthetic indicators in order to verify the changes of $\mathrm{pH}$ according to the color variation, currently these valuation processes do not use natural indicators, generating inconveniences in the response produced by the discharge and response processes, a negative impact on the environment environment ${ }^{1,5,7}$. Anthocyanins to red (increases in methoxylation $)^{4}$, the color of anthocyanins becomes more resistant to variations in $\mathrm{pH}$ when found as products condensation with catechins in the presence of aldehydes $^{3}$, presenting 4 different stable structures: flavonous ion, chalcone, quinoidal and pseudobase.

The extract of the arils of the fruit Punica granatum L. (pomegranate), presents a high content of anthocyanins, which are basic organic substances and have a protonated version; among the main properties are their diversity of colors, which makes them possible $\mathrm{pH}$ indicators ${ }^{6}$; to which are attributed the high antioxidant capacity of pomegranate juice, which is associated with the prevention of cardiovascular diseases, obesity, diabetes and cancer $^{2}$.

\section{EXPERIMENTAL}

A manual separation was carried out to obtain the arils of the pomegranate, which were disinfected with a sodium hypochlorite solution, washing at the end with abundant water. The elaboration of the raw extract of the pomegranate was based on the methodology of Díaz, 2014; press through a nylon mesh to obtain the extract. It was then concentrated in a water bath, centrifuged ( 5 minutes), filtered and stored at a temperature of $-4{ }^{\circ} \mathrm{C}$ until analysis.

The extract was taken to a column of Amberlite XAD-7, with mobile methanol phase and was concentrated in a rotary evaporator at a temperature of $40^{\circ} \mathrm{C}$.

\section{Analysis by UHPLC-ESI-Q-Orbitrap-MS/MS}

The sugar free fraction of the extract Punica granatum L., was dissolved in methanol (HPLC), taken to the Ultra Sound equipment and finally filtered, its separation was carried out in the Ultra High Performance Liquid Chromatography - Electrospray ionization - Quadrupole - Orbitrap - Mass Spectrometry (UHPLC-ESI-Q-Orbitrap-MS-MS), Reverse Phase C-18, coupled to a Mass Spectrophotometer (THERMO Q-Exactive) with quadrupole precursor, operated in Electro-Spray mode with positive ionization ( ES +).

\section{Elaboration of $\mathrm{pH}$ scale}

A buffer scale between a $\mathrm{pH}$ of 3.5 - 10 was prepared, transferring $5 \mathrm{~mL}$ of each buffer to test tubes labeled with $0.5 \mathrm{~mL}$ of the extract Punica granatum L., observing the color change in each of the tubes.

Analysis by UV-Vis spectrophotometry of the solutions in the range of 3.5 to $10 \mathrm{pH}$ units.

In the UV-Vis Spectrophotometer (Spectroquant Pharo 300) the wavelength displacement was analyzed as a function of the $\mathrm{pH}$ variation of the buffers previously discussed, in the presence of light and different fractions of time 5, 10 and 15 minutes.
Potentiometric titrations using Punica granatum $L$. extract as $\mathrm{pH}$ indicator.

The extract of Punica granatum L., free of sugars was evaluated as a natural $\mathrm{pH}$ indicator in the following potentiometric titrations:

a) Strong mono-protic acid $(\mathrm{HCl})$ and strong base $(\mathrm{NaOH})$

b) Weak acid $\left(\mathrm{CH}_{3} \mathrm{COOH}\right)$ and strong base $(\mathrm{NaOH})$

c) Strong diprotic acid $\left(\mathrm{H}_{2} \mathrm{SO}_{4}\right)$ and strong base $(\mathrm{NaOH})$

d) Strong triprotic acid $\left(\mathrm{H}_{3} \mathrm{PO}_{4}\right)$ and strong base $(\mathrm{NaOH})$

\section{Evaluation of Punica granatu L. extract in the presence of light.}

The stability in the presence of light of the sugar free extract was analyzed during a period of 7 days, being stored in an amber glass bottle and in a transparent and transparent glass bottle, to be later evaluated in the UV-Vis Spectrophotometer (Spectroquant Pharo 300).

\section{Statistical test t-Student}

The t-Student test allows comparing samples, $\mathrm{N} \leq 30$ and / or establishes the difference between the means of the samples ${ }^{8}$.

There are two versions of the t-Student test: one that assumes that the sample variances are equal and another version that does not assume the latter. To decide whether or not the equality of variance can be assumed in the two samples, the F-Snedecor test for the comparison of two variances must be carried out previously.

\section{Results and Discussion}

\section{Analysis by UHPLC-ESI-Q-Orbitrap-MS/MS}

The analysis in the equipment UHPLC-ESI-Q-Orbitrap-MS /MS provided the molecular weight of the structures present in the extract of the fruit Punica granatum $L$., because they are in ionized form in the solution.

Table 1. Anthocyanidic compounds, obtained from the analysis in the UHPLC-ESI-Q-ORBITRAP-MS / MS

\begin{tabular}{|c|c|c|c|}
\hline Compound Name & $\begin{array}{c}\text { Fragment } \\
\text { Weight }(\mathbf{m} / \mathbf{z})\end{array}$ & $\begin{array}{c}\text { Condensed } \\
\text { Formula }\end{array}$ & $\begin{array}{c}\text { Retention } \\
\text { time (Min) }\end{array}$ \\
\hline Cyanidin - Diglucoside & $611.18 \mathrm{~m} / \mathrm{z}$ & $\mathrm{C}_{27} \mathrm{H}_{31} \mathrm{O}_{16}{ }^{+}$ & $19.1 \mathrm{~min}$ \\
\hline Cyanidin - Monoglycoside & $433.11 \mathrm{~m} / \mathrm{z}$ & $\mathrm{C}_{21} \mathrm{H}_{21} \mathrm{O}_{11}{ }^{+}$ & $20.2 \mathrm{~min}$ \\
\hline Pelargonidin - Diglucoside & $595.18 \mathrm{~m} / \mathrm{z}$ & $\mathrm{C}_{27} \mathrm{H}_{31} \mathrm{O}_{15}{ }^{+}$ & $19.5 \mathrm{~min}$ \\
\hline Cyanidin & $287.06 \mathrm{~m} / \mathrm{z}$ & $\mathrm{C}_{15} \mathrm{H}_{11} \mathrm{O}_{6}{ }^{+}$ & $19.1 \mathrm{~min}$ \\
\hline Pelargonidin & $271.06 \mathrm{~m} / \mathrm{z}$ & $\mathrm{C}_{15} \mathrm{H}_{11} \mathrm{O}_{5}{ }^{+}$ & $19.5 \mathrm{~min}$ \\
\hline
\end{tabular}

*Corresponding author email: emilygarcia1993@hotmail.com 


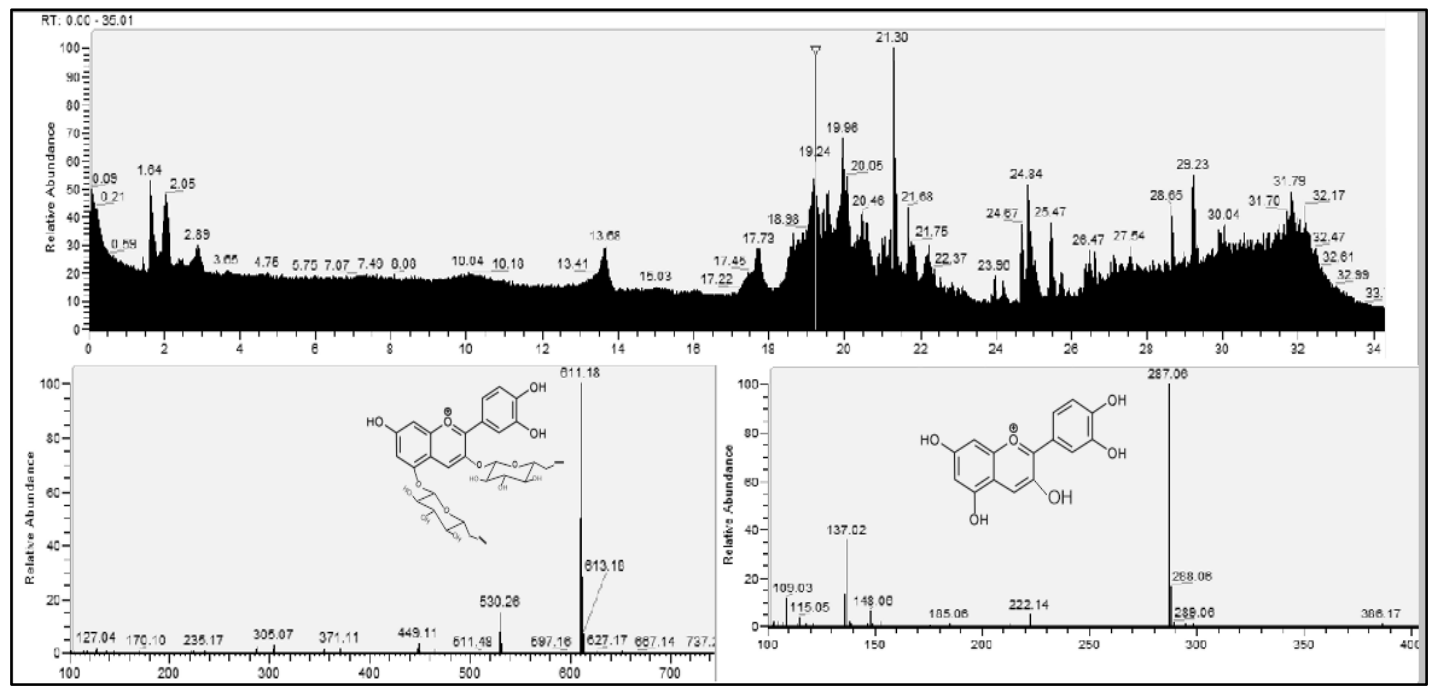

Figure 1. a) Chromatogram of the UHPLC (Reverse Phase C-18) of the extract of the Punica granatum L. b) Spectrum of Ms of the anthocyanin (Cyanidin) 3,5 Di-glucosidada c) Spectrum of Ms / Ms of the anthocyanidin (cyanidin).

Source: Chromatogram obtained from the UHPLC -ESI-Ms / Ms. THERMO SCIENTIFIC - University of Antofagasta - Chile.

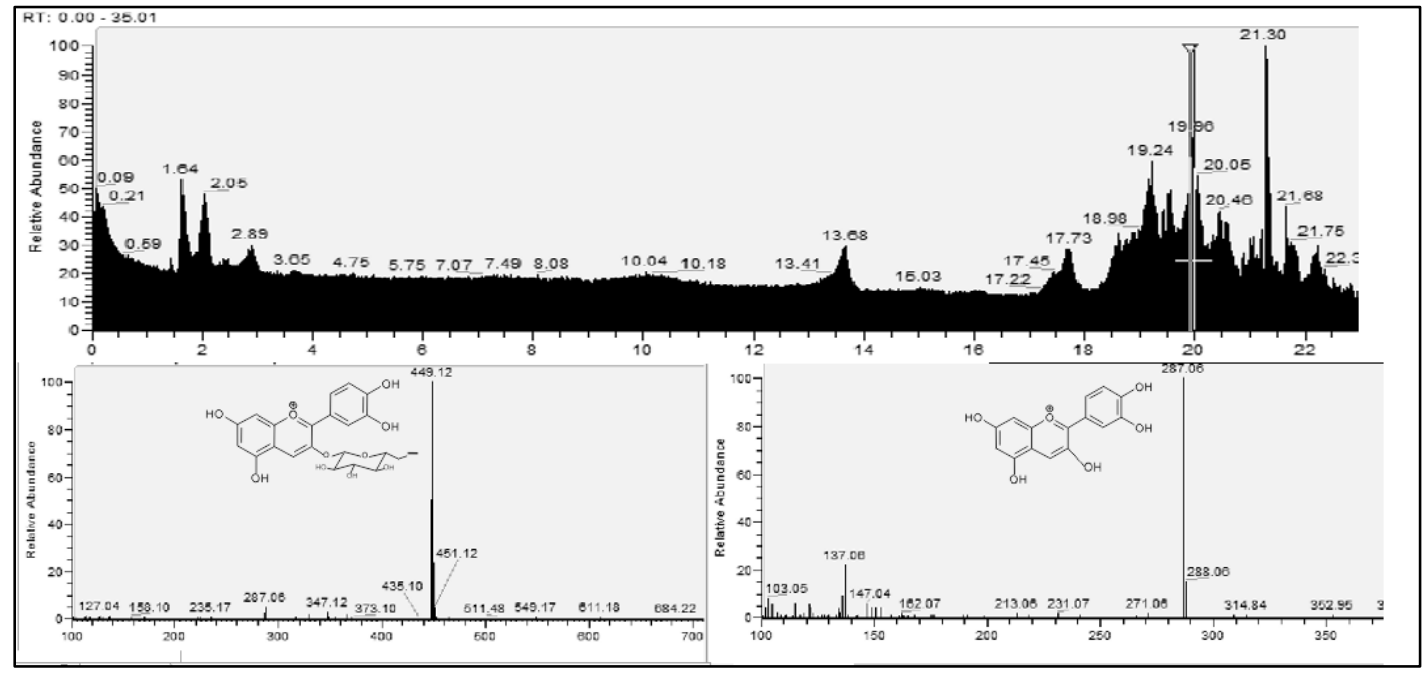

Figure 2. a) Chromatogram of UHPLC (Reverse Phase C-18) of the extract of Punica granatum L. b) Spectrum of Ms of anthocyanin (Cyanidin) 3 Monoglucosidada c) Spectrum of Ms / Ms of anthocyanidin ( Cyanidin).

Source: Chromatogram obtained from the UHPLC -ESI-Ms / Ms. THERMO SCIENTIFIC - University of Antofagasta - Chile.

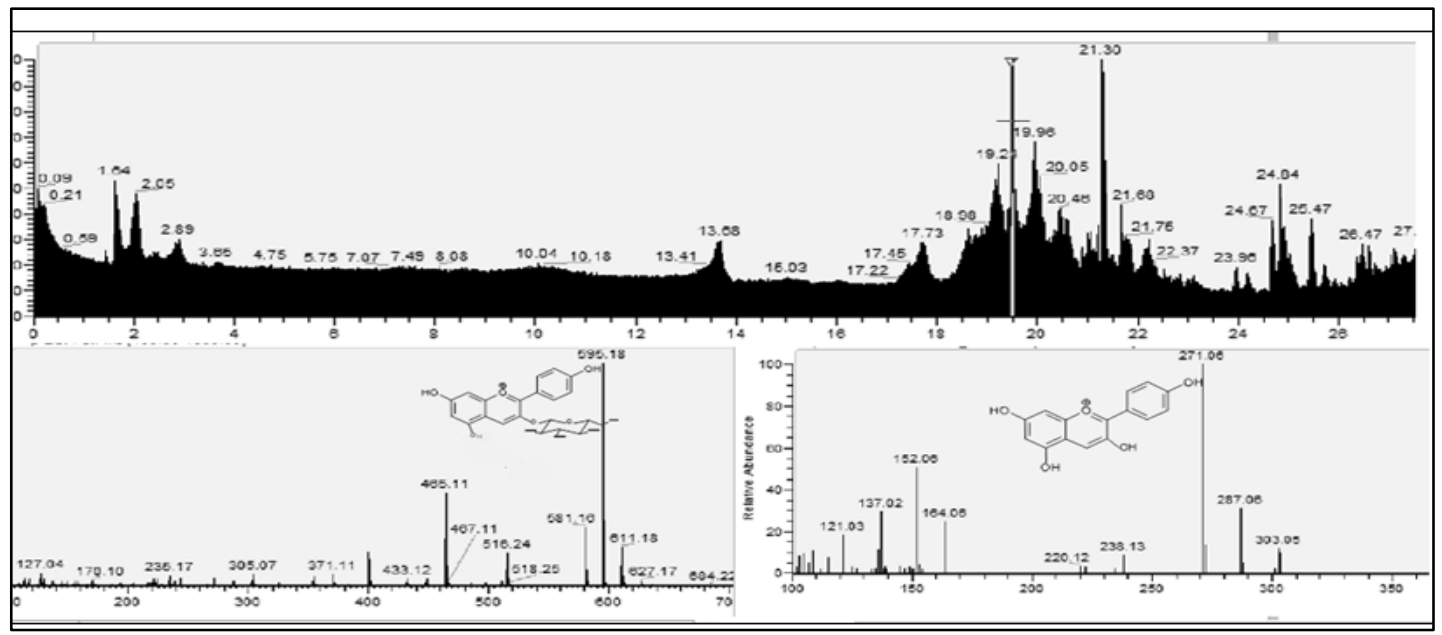

Figure 3. a) Chromatogram of HPLC (Reverse Phase C-18) of the extract of Punica granatum L. b) Spectrum of Ms of anthocyanin (Pelargonidin) 3 Monoglucosidada c) Spectrum of Ms / Ms of anthocyanidin ( Pelargonidin).

Source: Chromatogram obtained from the UHPLC -ESI-Ms / Ms. THERMO SCIENTIFIC - University of Antofagasta - Chile. 


\section{Elaboration of $\mathrm{pH}$ scale}

In the buffer scale at $\mathrm{pH} 3.5-10$, the colors were observed: light pink, light purple, violet-blue and dark yellow.

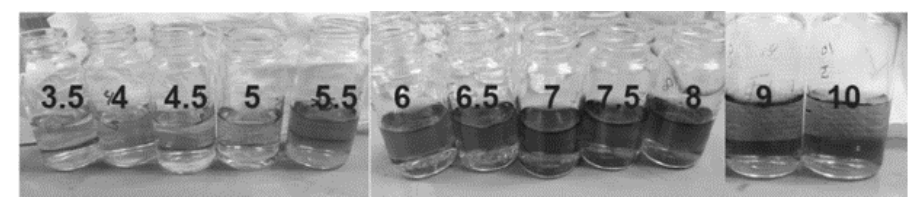

Figure 4. $\mathrm{pH}$ scale (3.5 - 10), with the fruit extract Punica granatum L.

Analysis by UV-Vis spectrophotometry of the Punica granatum L. indicator solutions in the range of 3.5 to $10 \mathrm{pH}$ units

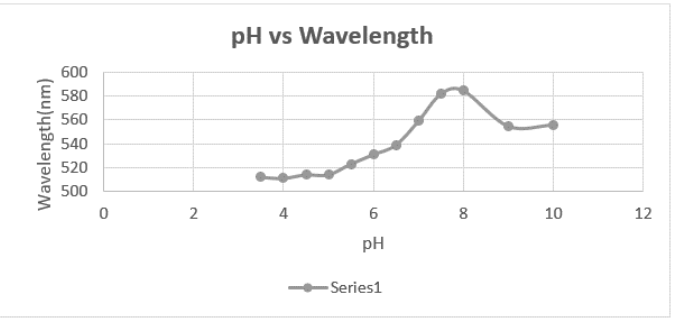

Figure 5. Variation of wavelength as a function of $\mathrm{pH}$ variation.

\section{Stability of Punica granatum L. extract in the presence of light.}

The $\mathrm{pH}$ scale $(3.5$ - 10) was analyzed in the UV-Vis Spectrophotometer (Spectroquant Pharo 300), after each time lapse (5, 10 and 15 minutes) to compare and evaluate the hyperchromic effect of the absorbance.

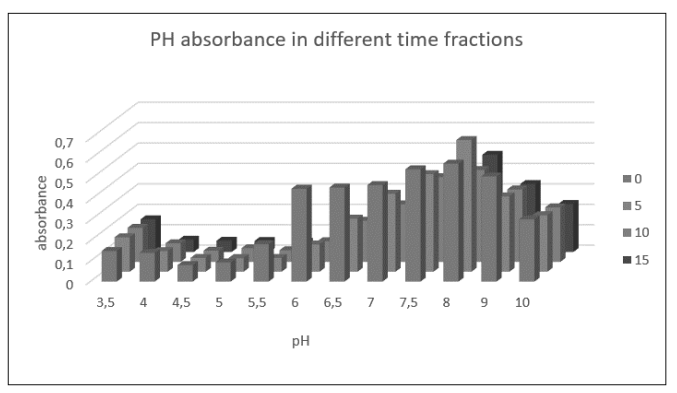

Figure 6. Absorbance of different values of the $\mathrm{pH}$ scale, in different fractions of time $(0,5,10$ and 15 minutes $)$.

Use of Punica granatum $\mathrm{L}$ extract as a $\mathrm{pH}$ indicator in potentiometric titrations

Strong monoprotic acid $(\mathrm{HCl})$ - strong base ( $\mathrm{NaOH})$

In the titration $\mathrm{HCl}$ vs $\mathrm{NaOH}$, initially it has a scarlet red color, that when arriving at the end point to neutral (green point) a yellow color is observed, with an expenditure volume of $30 \mathrm{~mL}$ at a $\mathrm{pH}$ of 8.27 , in addition to those obtained an equivalence point at $29.7 \mathrm{~mL}$ (red point).

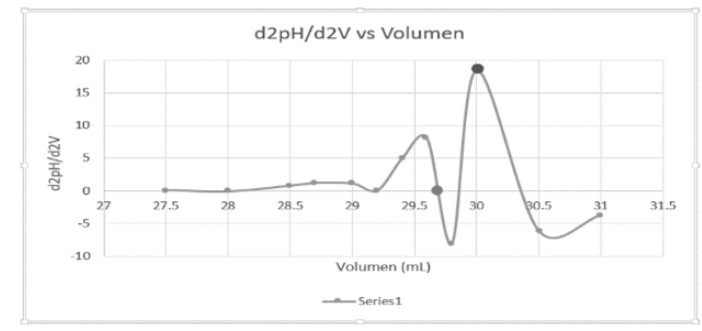

Figure 7. Curve of the second derivative of strong monoprotic acid $(\mathrm{HCl})$ vs strong base $(\mathrm{NaOH})$, using as an indicator the extract of Punica granatum $L$. Equivalence point (Red point) - End point (Green point).

\section{Weak acid $\left(\mathrm{CH}_{3} \mathrm{COOH}\right)$ - strong base $(\mathrm{NaOH})$}

In the titration $\mathrm{CH} 3 \mathrm{COOH}$ vs $\mathrm{NaOH}$, initially it has a pink color, that when reaching the final point or neutral (green point) a yellow color is observed, which was given at a volume of $35.4 \mathrm{~mL}$ at a $\mathrm{pH}$ of 8.36 . With the previous results, the equivalence point was obtained, being $35 \mathrm{~mL}$ (red point).

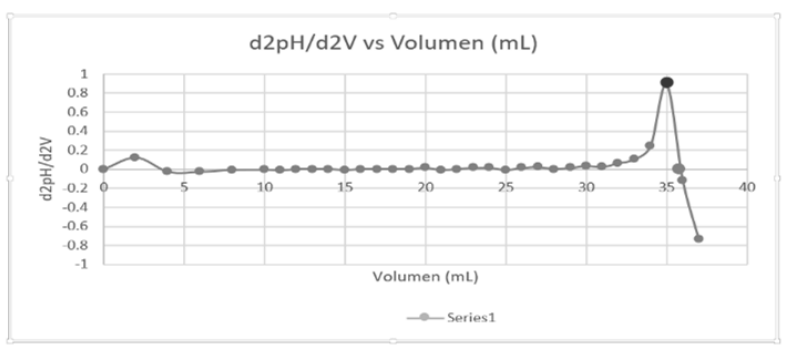

Figure 8. Curve of the second derivative of weak acid $\left(\mathrm{CH}_{3} \mathrm{COOH}\right)$ vs strong base $(\mathrm{NaOH})$, using as indicator the extract of Punica granatum L. equivalence point (Red point) - End point (Green point).

\section{Strong diprotic acid $\left(\mathrm{H}_{2} \mathrm{SO}_{4}\right)-$ strong base $(\mathrm{NaOH})$}

In the titration sulfuric acid $\left(\mathrm{H}_{2} \mathrm{SO}_{4}\right)$ vs. sodium hydroxide $(\mathrm{NaOH})$, initially it has a scarlet red color, that when arriving at the final or neutral point (green point) a yellow color is observed, which was given at a volume of $34 \mathrm{~mL}$ at a $\mathrm{pH}$ of 8.91. With the previous results, the equivalence point was obtained, being $33 \mathrm{~mL}$ (red point).

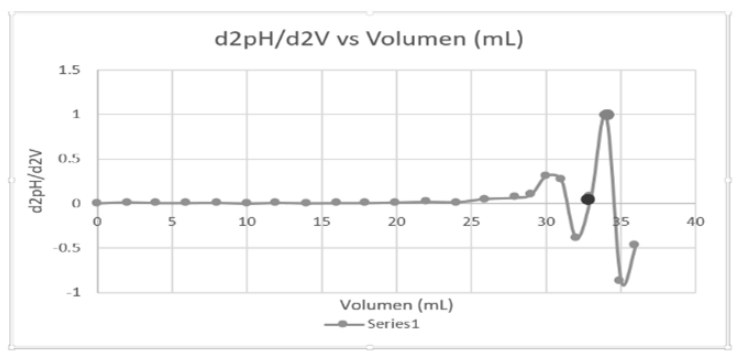

Figure 9. Curve of the second derivative of strong acid $\left(\mathrm{H}_{2} \mathrm{SO}_{4} 0.1 \mathrm{~N}\right)$ vs strong base $(0.095 \mathrm{~N} \mathrm{NaOH})$, using as indicator the extract of Punica granatum $L$. Equivalence point (red point) - end point (green point).

\section{Strong triprotic acid $\left(\mathrm{H}_{3} \mathrm{PO}_{4}\right)-$ strong base $(\mathrm{NaOH})$}

In the titration phosphoric acid vs. $\mathrm{NaOH}$, initially it has a scarlet red color, that when reaching the first end point or neutral (green point) the end point is observed a yellow color which was given at a volume of $26 \mathrm{~mL}$ and a $\mathrm{pH} 8.39$. With the previous results, the equivalence point was obtained, being $20 \mathrm{~mL}$ (red point).

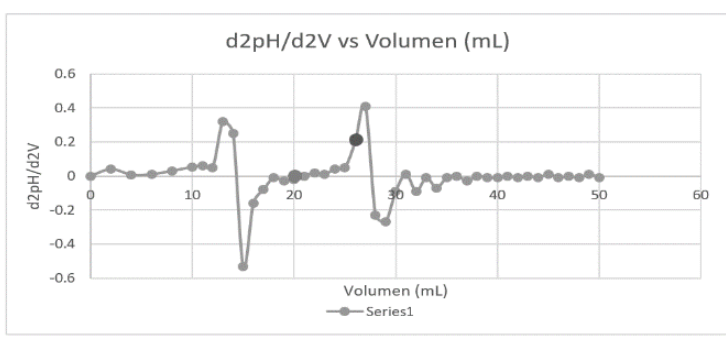

Figure 10. Curve of the second derivative of strong acid $\left(\mathrm{H}_{3} \mathrm{PO}_{4} 0.1 \mathrm{~N}\right)$ vs strong base $(\mathrm{NaOH} 0.095 \mathrm{~N})$, using the Punica granatum L. extract as an indicator Equivalence point (red point) - End point (green point).

\section{Determination of the $\mathbf{p K}_{\text {Indicator - }}$}

From the spectrophotometric study of the indicator, it was necessary to select a region of the scale where there is a clear and rapid change of the coloration associated with the abrupt variation of $\mathrm{pH}$, which occurs close to $\mathrm{pH} 7$, because an analysis was made in Function to the $\mathrm{pH}$ buffer scale. 
Table 2. Values of $\mathrm{pK}_{1}$ as a function of $\mathrm{pH}$

\begin{tabular}{|c|c|c|c|}
\hline Number & $\mathbf{p H}$ & Absorbance & \\
\hline 1 & 6 & 0.455 & \\
\hline 2 & 6.5 & 0.461 & \\
\hline 3 & 7 & 0.473 & \\
\hline 4 & 7.5 & 0.55 & \\
\hline 5 & 8 & 0.578 & \\
\hline 6 & 1.5 & 1.018 & $\mathrm{a}=$ Ain \\
\hline 7 & 10 & 0.305 & $\mathrm{~b}=$ Hin- \\
\hline
\end{tabular}

Table 3. Range of $\mathrm{pK}_{1}$

\begin{tabular}{|l|l|}
\hline Average of pK1 & 7.5034 \\
\hline pH $=$ pK1 $-/+\mathbf{1}$ & $(6,5-8,5)$ \\
\hline
\end{tabular}

Stability in the presence of oxygen and light from the extract Punica granatum $L$.

The study of the stability of the extract of the fruit Punica granatum L., in the presence of light, was carried out for 7 days and the characterization was carried out in the UV-Vis spectrophotometer (Spectroquant Pharo 300).

Table 4. Stability in the presence of light as a function of the absorbance of the two glass bottles (colorless and amber).

\begin{tabular}{|c|c|c|c|}
\hline & & Colorless glass bottle & Amber glass bottle \\
\hline Days & Dates & Absorbance & Absorbance \\
\hline 0 & 15-May-2017 & 0.77 & 0.77 \\
\hline 1 & 16-May-2017 & 0.593 & 0.366 \\
\hline 2 & $17-$ May-2017 & 0.495 & 0.439 \\
\hline 3 & $18-$ May-2017 & 0.496 & 0.452 \\
\hline 4 & 19-May-2017 & 0.565 & 0.452 \\
\hline 5 & 20-May-2017 & 0.533 & 0.416 \\
\hline 6 & 23-May-2017 & 0.497 & 0.371 \\
\hline
\end{tabular}

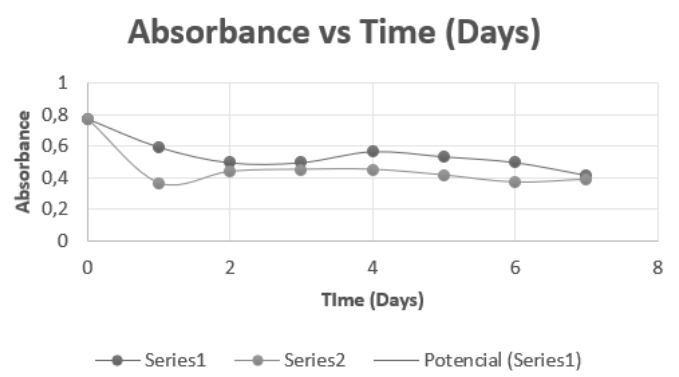

Figure 11. Absorbance comparison between two storage bottles, colorless glass (Series 1) and amber (Series 2), for a period of 7 days, $\mathrm{pH} 2.5$.

Statistical t-Student test to calculate the significance for the obtained data

Where:

- $\mathrm{H}_{0}$ : There is no significant difference between both storage bottles (amber and colorless)

- $\mathrm{H}_{1}$ : If there is a significant difference between both storage bottles (amber and colorless).

It is accepted $\mathrm{H}_{0}:-2.14479<\mathrm{T}_{\text {calculated }}<2.14479$.

It is rejected $\mathrm{H}_{1}: \mathrm{T}_{\text {calculated }}>2.14479$ ó $\mathrm{T}_{\text {calculated }}<-2.14479$.

Difference $\mathrm{T}$ test $=0($ vs. $\neq)$ : Value $\mathrm{T}=-1.50$ Value $\mathrm{p}=0.157 \mathrm{GL}=14$.

Therefore, the $\mathrm{T}$ value is in the acceptable range and $\mathrm{H} 0$ is accepted, revealing that there is no significant difference between both containers.

\section{CONCLUSIONS}

The acid - base titers (strong monoprotic acid - strong base and strong diprotic acid - strong base) with the extract of the pomegranate (Punica granatum $L$.) presented a rapid change of color in the range of $\mathrm{pH} 4.00-6.00$, due to the present instability of the anthocyanins, by the conjugation effect of the flavory cation or hydration of the $\mathrm{C} 2$ giving a chalcone structure (irreversible).

According to the statistic of the T-Student test at $95 \%$ confidence, there is no statistical difference between the values obtained from the stability test of the natural indicator by the action of light (stored in a transparent or amber glass bottle), both under the same conditions $\left(-4^{\circ} \mathrm{C}\right)$, so that said storage is ideal for the natural indicator in a period of 7 days.

\section{ACKNOWLEDGMENT}

To the National University Federico Villarreal, for the support in the "Contest of formative research projects" as part of the Thesis Seminar course and allow me to achieve this important achievement in my student life. Elizabeth H., Camila M., Mayra R., Nelson V. and that person who entered my life surprisingly (Melanie H. G.), which motivates me to continue in my dreams.

\section{REFERENCES}

1. Alas E. M. \& Salazar J. M. Obtención de Indicadores Naturales Ácido-base para medio Acuoso a partir del Fruto de la Fragaria vesca (Fresa), de las cascaras de Vitis vinífera (Uva Roja) y de la Prunus domestica (Ciruela Negra). Recuperado de la biblioteca digital de la Universidad de el Salvador. Facultad de Química y Farmacia. . (2010). p.p 1-184.

2. Díaz A. Calidad nutracéutica de extractos de Granada dulce y ácida y bioaccesibilidad de sus compuestos fenólicos en un modelo in vivo.(Tesis Magister).Mexico. Facultad de Quimica. Universidad Autónoma de Querétaro. (2014).

3. Fuentes W. Extracción, cuantificación y estabilidad de colorantes naturales presents en los frutos de Punus capuli Cav. (Cereza), RUbus urticaefolius Poir (Mora) y Sambucus canadensis L. (Saúco) como alternativas naturales de consumo de los colorantes artificiales rojo 40, Rojo 3 y Rojo 2., en bebidas en el rango de $\mathrm{pH}$ : 3, 4 y 5. Facultad de Ciencias Químicas y Farmacia. Universidad de San Carlos de Guatemala. (2005).

4. Garzón G, Antocianinas como colorantes naturales y compuestos bioactivos: Revisión. Departamento de Química. Universidad Nacional de Colombia. (2008).

5. Kun L., Pei L., Jun C., Shoujun X., Hu Y \& Aimin L. Efficient adsorption of both methyl orange and chromium from thier aqueous mixtures using a quaternary ammonium salt modified chitosan magnetic composite adsorbent .Nanjing University. (2016).

6. Marcondes J., Domingos M., Pereira F., De Sousa A., Figueiredo A. \& Dominguini L. Estudo da Estabilidade de Antocianinas em Diferentes Alcoóis Alifáticos para uso como Indicador de pH. Revista Ciencias Exactas e Naturales. (2014).

7. Pavan F. A., Lima E. C., Dias S., Mazzocato A. C., Methylene blue bioosorption from aqueous solutions by yellow passion fruit waste. Instituto de Quimica, Universidade Federal do Rio Grande do Sul. (2007). p.p.703717.

8. Sánchez R., (2015). T-Student. Usos y abusos. UMAE Hospital de Cardiología, Centro Médico Nacional Siglo XXI, IMSS. 